\title{
May 1835
}

/63r cont'd/ Friday May $1^{\text {st }}$.

Went down to Hotel Dieu this morning. Sanson's case of operation going on very well. Roux has several cases of strumous affections of the carpus ${ }^{1}$ - he has also a carcinomatous affection of the lower lip under his care - this is an awkward case - he will operate tomorrow morning the tumor is broad at the inferior as at the superior edge - hence a $\mathrm{V}$ shaped incision cannot be practised - the tumor besides is of considerable size \& under the jaw is an enlarged gland $-\mathbf{R}$. is evidently himself $/ 63 \mathrm{v} /$ at fault - there must be considerable deformity. This is the grand Fête du Roi - St. Philip's day ${ }^{2}-\&$ a day of National rejoicing. In the Champs Elysées were erected theatres, orchestras etc etc for the performance of trifling pieces - for concerts dancing \&c. this commenced at $21 / 2$ P.M. ${ }^{3}$ In the morning L. P. held a Levée, as miserable an affair as was ever dignified with such a name in this world. The Champs Elysées exhibited a most extraordinary sight today - covered with crowds of persons, mostly well dressed \& well behaved. Sports of all kinds, gratuitous as well as those for which one paid were going forward. In one part one may observe a pair of scales erected to weigh any person who chose to pay a couple of sous, in another a measure to take $y^{r}$. height ${ }^{4}$ - here a mountebank ${ }^{5}$ with a very powerful electrical machine, ${ }^{6}$ amusing the gaping crowd by some of the extraordinary experiments of Electricity - here a man with a lottery for Gingerbread. ${ }^{7}$

\footnotetext{
${ }^{1}$ Carpus: the wrist.

${ }^{2}$ The Fête du Roi was the annual celebration of the monarch, Louis Philippe.

${ }^{3}$ The original plantation on which the Champs Élysées was developed in 1616 was for the exclusive use of the Queen, Marie de' Medici. At the time of the diarist's stay, it was open to the public and was the most fashionable promenade in Paris where smart, springed carriages drove up and down. It extended along the Seine from which it was separated by the road leading to Versailles. In 1828 a bronze equestrian statue of Louis XV was erected. Several public fêtes took place along the Champs Élysées. (Galignani's new Paris guide, pp. 576-80.)

${ }^{4}$ In the early nineteenth century it would have been a novel experience to be weighed, since weighing scales were not at all widely available. Discovering one's height would also have been interesting and worth a couple of sous.

${ }^{5}$ Mountebank: not surprisingly, the diarist would have seen such a person, especially if he was offering any form of cures for illnesses, as an itinerant quack, a charlatan with impudent pretence to skills and knowledge which he did not possess. Such individuals, as well as usurping the role (and remuneration) of qualified physicians, were seen to undermine their status.

${ }^{6}$ Electrical machine: there was increasing interest in the phenomenon of electricity among the developing group of scientists in England and on the continent including France. Mary Shelley had referred to an electrical machine in her tale of Frankenstein (1818). It is small wonder if the mountebank drew large crowds to witness what would have been such a novel and, to many, frightening phenomenon.

${ }^{7}$ Lottery: in the fifteenth century there were lotteries in Paris, and Louis XIV held them also, but the prizes went to his favourites. Louis XV allowed lotteries to be held when money was needed for convents or churches, but Louis XVI suppressed them except when the proceeds went to the Hospice des Enfans Trouvés (orphans), the Hôpital de la Pitié and the Loterie Royale de France. The Loterie Royale, the details of whose directors and inspectorate were published annually in the Almanach royal et national, had its headquarters in rue Neuve de Luxembourg. On 16 November 1794 lotteries were abolished by the National Convention as immoral, but on 30 September 1797 the lottery of France was re-established. (Galignani's new Paris guide, pp. 574-5.) Country people played a sort of roulette for gingerbread-nuts and macaroons, which were often gilded and so in the sunlight would have sparkled and attracted customers. The diarist may have been observing this practice at the fête.
} 


\section{May 1835}

Jugglers; Mountebanks - Shooting with pistols ${ }^{8}$ \& crossbows $^{9}$ at marks - throwing the Quoits, a kind of "bowl \& ninepins" 10 - swings of all kinds, some very ingenious - beer a sous a glass etc etc - forming the most extraordinary \& the most mottley [sic] assembly I ever saw - the pieces represented at the theatres were very stupid-military - $\&$ the theatres themselves were decorated with the names of Napoleon's most celebrated victories. As it was somewhat warm \& I was tired, I did not wait to see the dancing - hear the concerts or view the boys climb /64r/ a greasy pole with other such feats. ${ }^{11}$ After dinner I went up to the Tuilleries again. An orchestra had been erected opposite the Pavilion d'horloge $[\text { sic }]^{12}$ from which at $71 / 2$ P.M. the Military band commenced playing - but [no] sooner had they begun - than there was a general cry of "Marseillaise" which completely drowned the music \& soon after the mob struck up the hymn - to the infinite annoyance of myself $\&$ others, who had been attracted thither by expectations of music, \& no doubt, to the no little dissatisfaction of Louis Philippe ${ }^{13} \&$ the courtiers. I soon left this noisy scene - by this time the illumination had commenced - the Tuilleries was not very well illuminated - but the garden was beautiful, lamps hanging in beautiful festoons from trees throughout all the walks - the ponds surrounded by the same - some houses in the R. de Rivoli also lighted up - on coming down into the Place de [la] Concorde - we came to the most beautiful part the magnificent Hotel of the Minister of the Marine ${ }^{14}$ was very tastefully decorated with lamps disposed along the whole front of the building on the top of the colonnades - the Chamber of deputies did not show itself so well, as the lamps were not quite close enough together - behind we had a view of the Chateau of the Tuilleries, \& the gardens $\&$ in front the magnificent promenade leading from the Place de la Concorde to the Barrière d'Etoile $^{15}$ - the whole of this alley was brilliantly illuminated with lamps in festoons

\footnotetext{
${ }^{8}$ Duelling, although illegal, still occurred in France and skill with a pistol was a useful attribute.

${ }^{9}$ Crossbows were medieval weapons consisting of a bow fixed across a wooden stock, having a groove or barrel for the missile and a mechanism for holding and releasing the string. They were used for shooting bolts, stones and arrows. Whilst they may still have been used in rural areas, skill with a crossbow may have been comparable to an interest in archery today.

${ }^{10}$ Bowl and ninepins: the French have a traditional Provençal game similar to bowls called pétanque.

${ }^{11}$ In view of the itinerant nature of this genre of entertainers it is not surprising that so many of the entertainments, even at this time, were similar to those back at home and hence may have engendered in the diarist a form of déjà vu.

${ }^{12}$ The Pavillon de l'Horloge was one of the five pavilions which made up the Palace of the Tuileries and which faced the courtyard. It had Ionic and Corinthian columns of red and brown marble and a pediment bearing the arms of France. (Galignani's new Paris guide, p. 153.)

${ }^{13}$ The King - and it seems the diarist was probably a Royalist - would certainly not have approved of this spontaneous interruption of the planned progamme by "the mob" with the singing of the revolutionary hymn, the Marseillaise. It could have hinted at events to come.

${ }^{14}$ Hôtel of the Minister of the Marine was a magnificent building, formerly occupied as the "garde-meuble de la couronne", and contained many valuable objects including furniture and jewels of the crown. On the night of 16 September 1792 a robbery took place but most of the stolen goods were recovered and dispersed for safety at that period of the Revolution. Under Napoleon the building became the residence and offices of the Minister of the Marine (Navy) and Colonies, who was still living there when the diarist was in Paris. On the roof, a telegraph was erected to correspond with Brest. (Galignani's new Paris guide, pp. 256, 284-5.)

${ }^{15}$ Probably from the late period of Roman occupation, Paris, which then consisted mainly of the Île de la Cité, had begun to acquire walls to defend its boundaries. As the city enlarged over time so successive walls were replaced and extended. For example, in 1190 Philip Augustus, prior to his departure on a crusade to the Holy Land, commanded the householders of Paris to surround the city with a substantial wall having turrets and gates. It is these gates and their successors which are known as the barriers or barrières such as the Barrière de l'Étoile to which the diarist refers. (Galignani's new Paris guide, pp. 585-7.)
} 
hung between the trees - soon they commenced the "Jeu de Feu"16 on the Pont de [la] Concorde. Some of the fireworks were magnificent, but did not continue as long as I expected, only /64v/ about 20 minutes - I then walked up into the Champs Elysées - this was probably the most amusing scene of all - the whole Champs lighted up splendidly - the motley crowd - the various peeps ${ }^{17}$ of the Tuilleries - the Hotel des Invalides ${ }^{18}$ handsomely illuminated \&c. In the Grand Square they were still going on with the scenic representations - with bands etc but the concert was over. In the opposite side of the Champs we stumbled on some dancing places, open to the Public at 5 sous par tête - we ent $^{\mathrm{d}}$. here \& looked on a little at the dancing. It was rather too crowded to be much enjoyed - the men appeared to me most ill fav ${ }^{d}$. creatures $-\&$ very awkward - they might possibly by the French be admired, but to my mind there was nothing more wretched than their display - I question, whether our clowns in England $w^{\text {ld }}$. not dance better - but the females amply made up for this defect on the part of the Lords of Creation - they exhibited an immense deal of grace - more than is generally shown by the best circles in the English Ballrooms - I was exceedingly pleased with their appearance - I made here the same observation, as I have remarked several times before - that the French women are by no means as a body, pretty, not nearly so generally as the English ladies - but their figures are "trés jolies" \& their feet \& ankles above all praise - there is something also in their face which is very attractive smile also is very arch, \& somewhat libidinous - as usual plenty /65r/ of English of both sexes everywhere ${ }^{19}-$ ret $^{d}$.- took cup of coffee \& got to bed about $12 \frac{1}{2}$.

Saturday $2^{\text {nd }}$.

Could not get to sleep last night 'till very late on account of taking coffe $\mathrm{e}^{20}$ just before going to bed - did not in consequence get to the Hospital this morning - observed that the Tribune, in allusion to the "fête" yesterday, gave a long extract from the Moniteur ${ }^{21}$ of 1794 -giving

\footnotetext{
16 "Jeu de Feu": firework display, which in this instance the diarist cannot help admiring. He was clearly impressed and may never have seen such a display in England.

${ }^{17} \mathrm{He}$ would seem to be referring to the incidents of catching and losing sight of the Tuileries between the trees, etc. as he walked along.

${ }^{18}$ The Hôtel des Invalides was the first establishment in France for military invalids. It was founded in 1596 by Henri IV. Originally in an ancient convent, it was later transferred to a new building erected in 1670 by Louis XIV who was determined to provide an edifice "commensurate with the object of its destination".

(Galignani's new Paris guide, p. 221.) This grand building later became the mausoleum of Napoleon Bonaparte.

${ }^{19} \mathrm{~A}$ clear indication of the considerable size of the English community in Paris at that time.

${ }^{20} \mathrm{He}$ shared the long standing belief in the sleep-destroying property of coffee taken late at night, probably more pronounced among the English than the French, who thought that tea was worse than coffee in this respect.

${ }^{21}$ Le Moniteur Universel is listed by Galignani as an "official journal" in contrast to thirteen other newspapers which are listed as "political". It cost 28 francs a quarter and was published at 6 rue de Poitevins. (Paris guide, p. lxii.) The 1830 s Moniteur Universel was clearly a pro-monarchy publication. On 2 May 1835 , it printed on its front page an account of the fête of the previous day, representing it as a most enjoyable and orderly occasion in which, "there could be seen among the crowd, a large number of foreigners and persons of distinction, who had come to participate in the popular entertainments" ("au milieu de la multitude on reconnaissait un grand nombre d'étrangers et de personnes de distinction, qui venaient s'associer aux divertissemens populaires"). Like the diarist, the paper rated the firework display and illuminations as "magnifique". (Le Moniteur Universel, no. 122, samedi, 2 mai 1835.) The 1794 issue of the newspaper was dated according to the French Revolutionary calendar: "13 Floréal, l'an 2 de la République Française", but also carried the non-revolutionary Gregorian date " 2 mai 1794, vieux stile".
} 


\section{2-3 May 1835}

an account of the deputation of the different authorities \& from the club of the Jacobins ${ }^{22}$ to the Nat ${ }^{1}$. Convention, ${ }^{23}$ the first anniversary of the death of the King - it introduced the subject with very great naiveté \& adroitness - wishing to insinuate that there was some degree of parallelism between them, or that there ought to be - the other papers of the Liberal or Revolut ${ }^{\mathrm{y}}$. side are also very violent $\&$ insinuating - particularly the Charivari. ${ }^{24}$ Attended at Guersant's today - got over the amputat ${ }^{\mathrm{n}}$. of lower extremity.

\section{Sunday $3^{\text {rd }}$.}

As I was going to church this morning met two friends, who were going to $S^{t}$. Cloud to see the fête ${ }^{25}-I$ therefore accompanied them $-S^{t}$. Cloud is at the distance of two leagues ${ }^{26}$ from Paris - the road, by which we went lies thro' the Bois de Boulogne - this is a wood of considerable extent - the trees are now of very small size, as the old ones were all destroyed to make firewood for the allied armies in 1815 , at least so say the Parisians, but I can scarcely imagine this, as the allies ent ${ }^{\mathrm{d}}$. Paris during the summer, when there was not much necessity for firing. ${ }^{27}$ The Chateau is delightfully situated not far from the road - commanding an bentiftu extensive view tho' not what I sh ${ }^{\text {d }}$. call exactly beautiful - the Seine can be seen, but does $/ 65 \mathrm{v} /$ not preserve a sufficiently meandering course - but runs in almost a straight

\footnotetext{
${ }^{22}$ The Jacobins were members of a French political club or society established in 1789, and associated with the Revolution, to maintain and propagate the principles of extreme democracy and absolute equality. It came to be applied to sympathisers of the Jacobins of the Revolution and around 1800 was used as a nickname for any political reformer. Alfred Cobban, a non-Marxist revisionist historian, in his social interpretation of the French Revolution as a revolution of the middle classes and the better off peasantry refers to the class conflict within the ranks of the peasantry which included the agrarian landless poor. He cites the work of fellow social historians, some of whom saw the Robespierreist faction of the Jacobins as protectors of landowning capitalists. (Cobban, The social interpretation of the French revolution, pp. 120-1.)

${ }^{23}$ The National Convention was the appointed assembly which governed France from 21 September 1792 to 26 October 1795. According to the Gentleman's Magazine of August 1792 (p. 759), "The French Nation is invited to form a National Convention".

${ }^{24}$ Le Charivari was one of the most important satirical journals in nineteenth-century France. It took its name from the noisy village rituals that made cruel fun of those who did not conform to what was acceptable socially. The great caricaturist Honoré Daumier (1808-79) was a contributor from 1839.

${ }^{25}$ The town of St. Cloud with its palace and beautiful grounds, not too far from either the grander and more famous palace of Versailles or the porcelain factories of Sèvres, had long associations with the French monarchy. Its steep streets provide a delightful view of the Bois de Boulogne. The palace was purchased in 1728 by Louis XVI for Marie Antoinette, who greatly enjoyed the time she spent there, as did Napoleon, who took over the palace and frequently dealt with affairs of state there rather than in Paris. The main fête of St. Cloud took place in the park during three weeks in September and was the most celebrated fête in the vicinity of Paris, attracting immense crowds particularly on Sundays. Galignani's description of the crowds, amusements and music, which "resounds to a great distance", gives the event the air of an annual pop festival. The diarist seems to have been attending a much more modest summer Sunday fête. (Galignani's new Paris guide, pp. 667-79.)

${ }^{26}$ Leagues: the distance represented by a league varied according to the country. It was usually established as about three miles.

${ }^{27}$ The extensive woodland of the Bois de Boulogne, in which the rich showed off their fine horses and carriages, was about two miles from the city. Galignani explains that the wood, which at the time of the Revolution was of poor quality, was used by the revolutionary groups. Later, in 1814, trees were felled to make palisades against the invading armies. Galignani's description does, however, support the claim that the wood from the Bois de Boulogne was used by the Allied armies, because in July 1815, following the capitulation of Paris, the British troops under the command of the Duke of Wellington established their camp in the Bois de Boulogne. To construct huts, rather than fires, the trees were cut down and after the army's removal replanting eventually took place. The Bois de Boulogne had an even longer association with "gun battles" of another order - duelling - and at the time of the diarist's visit it had seen several thousand Parisians and foreigners perish on its soil. (New Paris guide, pp. 580-1.)
} 


\section{3-5 May 1835}

line, except the curve it makes, as it passes along the foot of the terrace - the remainder of the view is composed of a dull flat amphitheatre (surrounded on every side by slight elevations termed hills, in these flat countries) in the middle or rather at one extremity of which lies Paris \& its faubourgs ${ }^{28}$ - there is not a single tree in the whole view except in one spot near the river. At 3 o'clock the company began to assemble. Since I left England I have not seen so many English collected together - more than every second person belonged to our isles -I think, I may say, that never have I seen so fine an assemblage of beauty, as in this place indeed there were two or three splendid creatures - I was particularly amused with an old fat English Dowager walking about with her three daughters, very fine creatures - but unfortunately too well aware of it \& too much accustomed to command admiration - the old mother kept parading them up \& down in front of the company - as much as to say "Come who will buy". At 4 the waters began to play - these were remarkably fine, tho' not so magnificent, it is said, as those at Versailles ${ }^{29}$ - exceedingly expensive-cont ${ }^{d}$. about twenty minutes - at one side there was a single spout from which water issued, ascending considerably higher than the neighbouring trees. /66r/ After the waters had ceased, we walked thro' the grounds, these are pleasant, but not so agreeable as those of many Gent ${ }^{\mathrm{n}}$. in England, because less natural - from the highest spot was a town used by Napoleon as a telegraph to communicate with Paris - this is the favourite residence of the present King in Summer, probably because of of its contiguity to Paris - for he dares not remain long out of sight of this town. ${ }^{30}$ Afterwards went to one of the Restaurants, had a miserable dinner, paid dear \& walked home in the cool of the Evening quite tired.

Monday $4^{\text {th }}$.

Did not go to the Hosp ${ }^{1}$ this morning, but went round to inquire the price of watches, ${ }^{31}$ in order to be able to communicate with Mr. G.[?] on the subject.

Tuesday $5^{\text {th }}$.

Got a subject today at Clamart for $58 \mathrm{c}^{32}$ - commenced operations, tied all the arteries, I expect, I shall learn more from one such subject than from Guersant's whole course - wish I had not taken it - but fool \& his money are soon parted - Robert's course $w^{\text {ld }}$. have been well worth the money.

\footnotetext{
${ }^{28}$ Faubourgs: French for "suburbs".

${ }^{29}$ The magnificent palace and grounds of Versailles, which the diarist had not yet visited, had been initiated by Louis XIV in 1664 and were completed in 1702. The palace was situated in the large handsome town of Versailles, some distance from Paris. The gardens were renowned for their waters, including the Allée d'Eau in front of the baths of Diana and the numerous fountains with their beautiful statuary. The cost of constructing the palace and its grounds was in the 1830 s estimated to have been between $£ 30$ million and $£ 40$ million. It was believed that this expenditure by Louis XIV, details of which he is said to have destroyed, hastened the Revolution. (Galignani's new Paris guide, pp. 703-44.)

${ }^{30}$ Sensitive to political currents of the time, the King feared a resurgence of revolutionary activity.

${ }^{31}$ Perhaps like books the price of watches was lower than in England but the duty charged was among the highest levied. "Watches of all sorts, for every $£ 100$. value ... $£ 25$ ". Thus a watch valued at $£ 100$ would attract a tax of $£ 25$. (Galignani's new Paris guide, p. lxix.)

${ }^{32}$ The cost of anatomical dissection facilities was very reasonable. American students were particularly appreciative of them and considered the cost of bodies - 30 francs ( $£ 15 \mathrm{~s}$. or $\$ 6)$ in 1850 for an unlimited supply and the demonstrator's assistance for the whole winter - to be very modest. (Warner, Against the spirit of system, pp. 94-6.) See also January 19, note 123, on Clamart.
} 
Wednesday $\left[6^{\text {th }}.\right]$

Went down to Clamart, operating ${ }^{33}$ all day - cut myself unfortunately ${ }^{34}$ - trials commenced yesterday morning - already some row I believe. ${ }^{35}$

Thursday $7^{\text {th }}$.

Went down to Clamart again this morning - finished my subject - ret $^{d}$. home at $1 / 4$ past 5 found a note from $\mathbf{M}^{\mathrm{r}}$. Newstead inviting me to tea, hastened to get ready - finished two letters to be sent to England - took them down to $D^{r}$. Morris ${ }^{36}$ found he was gone - jumped into cab-got up to Faubourg $S^{t}$. Honoré in very good time - a very pleasant Evening as usual - several Wesleyan preachers - it appears to be a conference now. ${ }^{37}$

Friday $8^{\text {th }}$.

Great row yesterday at Chamber of Peers - they don't know what to do. ${ }^{38}$ Why not pardon the prisoners it $w^{\text {ld }}$. be L. P.'s ${ }^{39}$ most politic measure - I am happy $/ 66 \mathrm{v} /$ to find from Galignani's Messenger that there are no hopes of Lord J. Russel[1]'s election for Devonshire. ${ }^{40}$ This will teach him that the Conservative Interest " $n$ 'est pas encore tout à fait

\footnotetext{
${ }^{33}$ He means dissecting.

${ }^{34}$ Warner points out the risks of dissection: "A prick of the finger by the knife might be tersely mentioned as a routine diary entry, but it threatened the possibility of serious illness." Emily Blackwell who studied in Paris around 1850 believed that she had developed ophthalmia whilst treating an infant with the disease when on syringing its eye a drop of the water spurted up from the infant's eye into her own. She lost the sight of one eye and had to wear a glass one. (Against the spirit of system, pp. 113-14.)

${ }^{35}$ Regarding these trials, see entry for May 8.

${ }^{36}$ The diarist could be referring to Edward Morris from Hereford. He had gained an MRCS and an LSA in 1818 and was therefore someone the diarist would address formally. He later became an Licentiate of the Royal College of Surgeons London in 1844 and may already have been using the title "Dr.". He was the author of Suggestions for a reformation in the Church of England, and for the education of the people of the empire, which may indicate that he was not an Anglican and hence could have been someone with whom the diarist shared religious sympathies. (London and Provincial Medical Directory, 1849, p. 378.)

${ }^{37}$ This might be a more formal way of referring to a "gaggle" of Weslyans, especially since Paris was hardly likely to host a conference of Wesleyans and the diarist does not use an initial capital letter.

${ }^{38}$ The Chamber of Peers, which sat in the Palais de Luxembourg, formed at the time an essential part of the legislative power. It was composed of peers (pairs) possessing hereditary titles who took their seats at the age of twenty-five and voted at thirty. Members of the Royal family and the Princes of the Blood were peers in their own right but could sit in the chamber only at the King's command. The Chamber also included ecclesiastical peers with the appropriate titles. The sanction of the peers was necessary for the enactment of all laws, for consideration of crimes committed by its own members as well as for cases of high treason and attempts against the safety of the state. These issues were deliberated and voted upon behind closed doors. (Galignani's new Paris guide, pp. 26-7.)

${ }^{39}$ The death of Napoleon II in 1832 did not entirely remove the Napoleonic legacy and there were calls for a more democratic suffrage. At the same time, socialist ideas were spreading along with republicanism. The trial of members of a trade union (such organisations were forbidden by law) in Lyons in April 1834 triggered an armed uprising in the city, in which a small number of the Droits de l'Homme (Rights of Man) society were involved. Fighting against royal troops and artillery lasted several days. Some days later, the Droits de l'Homme group attempted an insurrection in Paris, which resulted in a cumbersome trial before the Chamber of Peers during which sympathisers of the defendants criticised the regime. This may be the trial to which the diarist is referring. (Beik, Louis Philippe and the July monarchy, pp. 36-41.)

${ }^{40}$ Lord John Russell (1792-1878) - created first Earl Russell in 1861 - had followed the family tradition as a Whig parliamentary reformer and was in 1813, although slightly under age, returned to Parliament for the family borough of Tavistock under a Tory government. In 1830 Russell had stood for and very narrowly lost Bedford, due it was said to the Wesleyans who had objected to some of his remarks on prayer. However, he regained
} 


\section{8-12 May 1835}

detruit". ${ }^{41}$ Guersant was today on Paracentesis ${ }^{42} \&$ removal of os uteri - did not operate today, because my hand is not well - it is considerably swollen, inflamed \& painful.

Saturday $9^{\text {th }}$.

Went down to the Hotel Dieu - Roux had several cases of cataract to operate on, Breschet has good case of dislocation of shoulder forwards of three month[']s standing - he has ordered the man to be bled \& poulticed $\&$ intends in two or three days to attempt reduction. Walked about all day with a friend, who was going to England. Do not feel at all well today very feverish - axilla painful - hand \& finger swollen.

Sunday $10^{\text {th }}$.

All my feverish symptoms have disappeared, but my hand \& axilla are much worse lymphatics inflamed all the way to the shoulder. Went to Rue d'Anjou - heard a very good sermon from Mr. Cork [Cook?]. My arm very painful determined, when I ret ${ }^{d}$. to employ Higginbottom's plan ${ }^{43}$ - applied caustic along the red lines formed by inflamed lymphatics, ${ }^{44}$ I think with good effect.

Monday $11^{\text {th }}$.

Feel certainly better today - axilla not to[o] painful, \& several lymphatics intercepted ${ }^{45}$ inflammat $^{\mathrm{n}}$. is evidently stopped for the present - do not know how long it will remain so. At Guersant's today of course did not operate.

/67r/ Tuesday $12^{\text {th }}$.

My arm is considerably better - indeed there is but little the matter with it now except the blisters which the Nitrate of Silver raised - these annoy me \& of course will for some time to

Tavistock, made a memorable speech in 1831 on the Reform Bill and was later recognised as the leader of the Whigs. The years 1831-35 saw a number of changes in the administration to which Russell could be said to have contributed through his introduction later of a Dissenters' Marriage Bill and legislation on Irish affairs including examination of the revenues of the Irish Church. These measures did not satisfy the dissenters, even through their ministers were now enabled to perform marriages. The diarist is commenting that Russell would not gain the southern division of Devon seat which he was seeking at the same time as he was re-elected for Tavistock on 30 April 1835. In fact Russell did win the south Devon seat on 10 May and chose to sit for it. (DNB, vol. 17, pp. 454-63.)

${ }^{41}$ This translates as "is not yet completely destroyed".

${ }^{42}$ Paracentesis: the operation of tapping, i.e. drawing off liquid in cases such as ascites or dropsy of the ovarium.

${ }^{43} \mathrm{John}$ Higginbottom, An essay on the application of the lunar caustic, in the cure of ... ulcers (1826), pp. 24-6, deals with the treatment of "punctures etc.". In his revised edition of 1829 , when he refers to silver nitrate rather than lunar caustic, Higginbottom deals with a range of puncture wounds and also includes a section entitled 'Of wounds received in dissection'. Higginbottom bases the section on his own experiences during the examination of dead bodies in 1813 and 1818 . One instance involved the examination of a puerperal case, during which he received a puncture which he merely subjected to washing. There followed pain, high temperature, great swelling of the hand, vomiting, chilliness, perspiration and increasingly severe headache. He also suffered enlargement of some axillary glands and the tonsils. He was bled and treated with calomel and saline and eventually recovered. He believed, however, that had he been treated with silver nitrate along the tracts of inflammation and on the swollen hand, he could have checked his adverse symptoms in the manner achieved by the diarist. (Higginbottom, An essay on the use of the nitrate of silver, 1829, pp. 81-5.)

${ }^{44}$ Ammoniacal caustic was recommended by Milne-Edwards and Vavasseur, who declared that it could be "administered with success for some skin eruptions" ("administrée avec succès dans certaines eruptions cutanées"). But the diarist seems to have used silver nitrate. (Nouveau formulaire, pp. 100-1, 115.)

${ }^{45} \mathrm{He}$ means the inflammation has stopped progressing. 


\section{2-15 May 1835}

come - I hope tomorrow to be able to operate at Guersant's again. I see by the papers, that the Tribune was sued yesterday for Nth. Time - it has now ceased to appear - the editor not being able to support so many actions - its different editors have at one time \& another been imprisoned for 39 years altogether. A most miserable day today - I do not know, what they mean by praising so highly the Parisian Climate - to my mind this $\mathrm{y}^{\mathrm{r}}$. it has not been at all better than the same months in England. They have probably here not so many fogs.

\section{Wednesday $13^{\text {th }}$.}

My arm is quite well now, but the lines produced by the caustic are still raw \& threaten to be so for some time to come - I have been exceedingly fortunate to escape without even an abscess in the axilla. Went down to Hotel Dieu this morning Breschet had some good casestwo of Fistula in Ano - in one of which he made several incisions - there being no less than 4 different fistulae - the other case was one of abscess in the cellular tissue, which he opened yesterday - this morning he readily discovered communication with the rectum ${ }^{46}$ - in all these 5 fistulae the opening occurred in the intestine immediately above the sphincter shewing the correctness of the opinion maintained by Syme. Guersant was today on operation for strangulated hernia \& artificial anus - his lectures are very superficial.

Thursday $14^{\text {th }}$.

Went down to the Hotel Dieu this morning - followed Roux - no very good cases - one of gonorrhael ophthalmia - afterwards came back to La Pitié to see a man, on whom the operation $/ 67 \mathrm{v} /$ of tracheotomy ${ }^{47}$ had been performed yesterday Evening - he was much better. Nothing in Galignani today - at Guersant's tied the arteries of the upper \& lower extremities - I must go some Thursday to the Hotel des Invalides to see Baron Larrey ${ }^{48}$ he commences his visit at 7 A.M.

Friday $15^{\text {th }}$.

Went down to Hotel Dieu - Saw a very large Goitre ${ }^{49}$ under Roux's care - I think from $R$ 's observations he has some intention of removing it by the knife, a foolish plan I sh ${ }^{d}$.

\footnotetext{
${ }^{46}$ This represents another fistula and makes the fifth fistula to which the diarist then refers.

${ }^{47}$ Tracheotomy: bronchotomy, an operation in which an opening is made into the larynx or trachea either to allow the air into and out of the lungs in diseases where the patient is unable to breathe through the mouth and nostrils, or extract foreign bodies which have fallen into the trachea, or to inflate the lungs in cases of sudden suffocation, drowning, etc.

${ }^{48}$ Baron Dominique Jean Larrey $(1766-1842)$ was famous as a military surgeon in the Napoleonic campaigns where he had developed a number of special techniques for dealing with battle injuries, including swift amputations. He was the chief surgeon at Les Invalides, the hospital for the veterans. Warren described him as a polite, short, corpulent man with a pleasant face and grey curls that fell down over the collar of the military coat which he wore during his visits. (Parisian education, pp. 80-1.) Weisz reproduces the painting Larrey on the battlefield by Charles Müller, of 1849 , showing Larrey standing heroic and tall amidst the battle and about to receive a surgical instrument with which to treat a wounded soldier at his feet. For the Académie de Médecine the painting was a celebration of surgery and military medicine. (Medical mandarins, p. 118.)

${ }^{49}$ Goitre: common name for bronchocele, in England also known as the Derbyshire neck. This disease was characterised by a tumour on the front of the neck and located between the trachea and the skin. It was thought to occupy the thyroid gland. The disorder was common in Derbyshire and in the Alps and other mountainous areas. According to Hooper, the cause of the condition was unknown but one theory associated it with the use of snow water. The condition was intially pain free and external medicines including mercurial plasters, whilst possibly delaying its progress, produced little effect. Internal medicines including pills of mercury containing calomel or the use of a solution of iodine were also tried. (Lexicon, p. 270.)
} 
think - but he will do anything for the sake of an operation ${ }^{50}$ - Breschet had a case this morning of fracture of the fibula. Guersant on Lithotrity.

Saturday $16^{\text {th }}$.

Went down to Hotel Dieu this morning. Nothing in Roux's ward - R. operated on a boy with stone - at Guersant's today performed resection ${ }^{51}$ of lower jaw - very tired today.

Sunday $17^{\text {th }}$.

Went to the Rue d'Anjou this morning.

Monday $18^{\text {th }}$.

Went to the Hopital des Enfans to get a certificate for Carnegie ${ }^{52}$ - did not succeed. On my return, found a letter from home with an order on Lafitte ${ }^{53}$ at 7 days after eight - however he paid me immediately. A miserable headache today, obliged to go to bed immed ${ }^{\text {ly }}$ after dinner.

Tuesday $19^{\text {th }}$

Feel quite well this morning. Went to Hotel Dieu - got a certificate from Roux for Carnegie performed at Guersant's amputations of upper extrem ${ }^{\mathrm{s}}$. - Ent ${ }^{d}$. to $\mathrm{Mad}^{\mathrm{e}}$. Lachapelle's course of Midwifery this Evening.

Wednesday $20^{\text {th }}$.

Paid $\mathrm{M}^{\mathrm{r}}$. Lecomte this morning, \& gave notice of my intention of leaving in a month - very hot today - Guersant gave today an interesting lecture on stricture of /68r/ [the] urethra with the various methods of treatment - as usual in those diseases, which are the most difficult of cure - there is the greatest number of methods $\&$ inst ${ }^{\text {ts }}$. - thus is it for strictures. J. Syme is the most successful practitioner I have ever seen-Mayor[?] has lately introduced a method of treating stricture by introduction of very large sound, which he introduced by a kind of rotation of its point - he says, in the most narrow strictures this inst ${ }^{\mathrm{t}}$. can be engaged more easily than a small bougie - they say, he has been several times successful since his arrival in Paris, but Dupuytren's is consid ${ }^{\mathbf{d}}$. the best.

\footnotetext{
${ }^{50}$ Surgeons in England would have disapproved of Roux's intention because surgery was not recommended in view of the enlargement of the arteries and the proximity of the tumour to the carotids in the neck. (Hooper, Lexicon, p. 270.)

${ }^{51}$ Resection: the surgical excision of a part of an organ, especially of part of the structures forming a joint.

52 It has not been possible to trace Carnegie, who may have been a fellow student.

${ }^{53}$ Order on Lafitte: there was a travel company called Lafitte, which probably also provided money order exchange facilities for travellers using its modes of transport, that is a form of travellers' cheques. Lafitte is also the name of the street (actually passage) in which was situated the Hôtel Byron where his father, John (it is unclear who this was) and two (unnamed) sisters stayed on their visit to Paris beginning Thursday, June 4. The order was probably to pay in advance for the family's accommodation in the hotel. The street, in the 9th arrondissement, had been named only in 1830 after a politician, Jacques Lafitte (1767-1844). (Hillairet, Rues de Paris, vol. 2, p. 12.) It was conveniently near Galignani's Library, rue Vivienne, and the Palais Royal.
} 
Thursday $21^{\text {st }}$.

Went to Hop ${ }^{1}$. $\mathbf{S}^{\mathrm{t}}$. Louis today - Lugol commenced his lectures on Scrophula - he divided this disease into 5 species - the tuberculous, catarrhal or mucous, cutaneous, of cellular tissue, \& of the bones - he traced to scrophula an immense number secondary affections probably correctly so - worms in majority of cases, convulsions, alopecia, ${ }^{54}$ deficiency of growth, rickets \& curvature ${ }^{55}$ - I fear he will have ent ${ }^{\mathrm{d}}$. a very little way into his subject, when I leave Paris - Most disgusting objects his patients are. At Guersant's performed amputations of the lower extremity.

Friday $22^{\text {nd }}$.

Went to Hotel Dieu this morning - nothing particular under Roux except a urinary abscess. I have seen him make several openings in different parts of perinaeum, scrotum - today he made an incision from the right groin mainly to the lumbilicus ${ }^{56} \&$ transversally across to the opposite inguen ${ }^{57}$ - the whole of these parts were undermined by fistulae - I fear he intends operating tomorrow morning on the case of bronchocele. Guersant today on nothing worth listening to - at $\mathbf{M}^{\mathrm{e}}$. Lachapelle's manoeuvred \& touchéed.

/68v/ Saturday $23^{\text {rd }}$.

Went down to Hotel Dieu - understood that Roux intended to operate on his case of "goitre" this morning - he however deferred it till Tuesday next - he had better let it alone. Went to Guersant's operations - he had no upper extremity - so had not much to do - was at $\mathbf{M}^{\mathrm{e}}$. Lachapelle's Manoeuvres in the Evening.

Sunday $24^{\text {th }}$.

Went to Rue d'Anjou twice today - a long walk. Heard two excellent sermons.

Monday $25^{\text {th }}$.

Went to Hotel Dieu this morning - Heard Clin'1 Lecture from Chomel. Afterwards went into Breschet's wards \& to his Consultation - he intends shortly to commence giving Clin'. Lectures - was at $\mathbf{M}^{\mathrm{e}}$. Lachapelle's Toucher \& Manoeuvres in Evening.

Tuesday $26^{\text {th }}$.

Went to Hotel Dieu this morning - M. Roux performed the operation on the man with Bronchocele - he extirpated the right half of the tumor \& the middle portion, but the left he allowed to remain in statu quo - he was an hour \& ten minutes in the performance of it, \& applied 37 ligatures - I presume he applied them on veins \& arteries both - he was close to,

\footnotetext{
${ }^{54}$ Alopecia: baldness or hair loss. The name is derived from the Greek word for fox, due, some thought, to the occurrence of a similar condition in the fox or to the belief that fox's urine would cure baldness.

${ }^{55}$ Curvature: distortions in the alignment of the spine.

${ }^{56}$ Lumbilicus: he means the umbilicus, the navel.

${ }^{57}$ Inguen: the groin, the lower and lateral front part of the abdomen, above the thigh.
} 


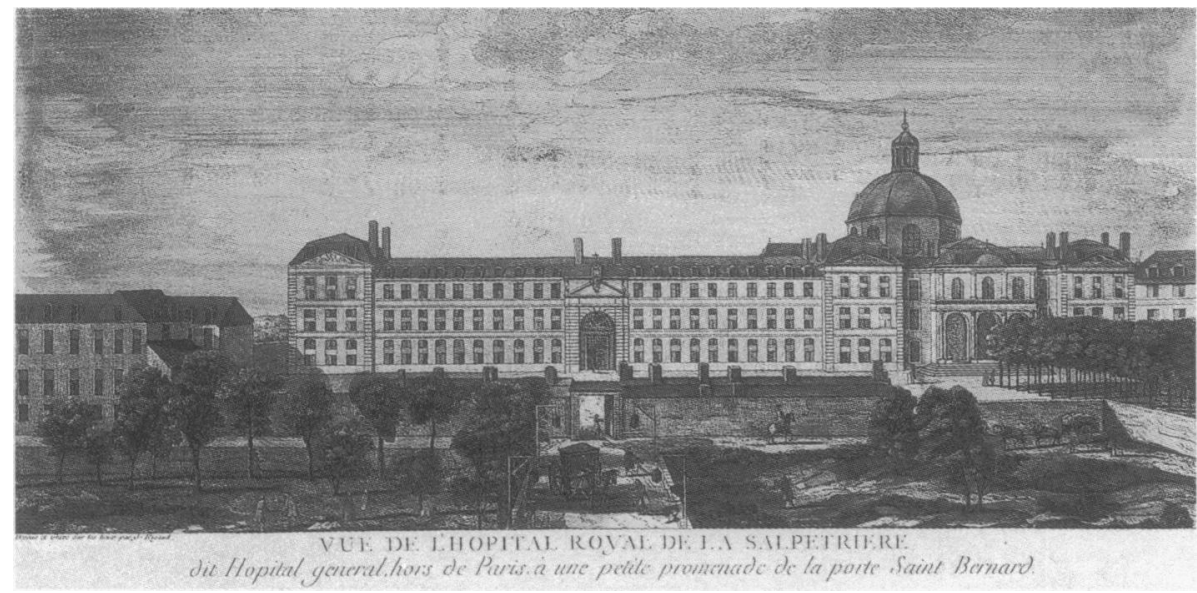

Figure 23: An eighteenth-century view of the Hôpital de la Salpêtrière, showing St. Bernard's doorway and grounds. Coloured line engraving by J. Rigaud after himself. (Wellcome Library, London.)

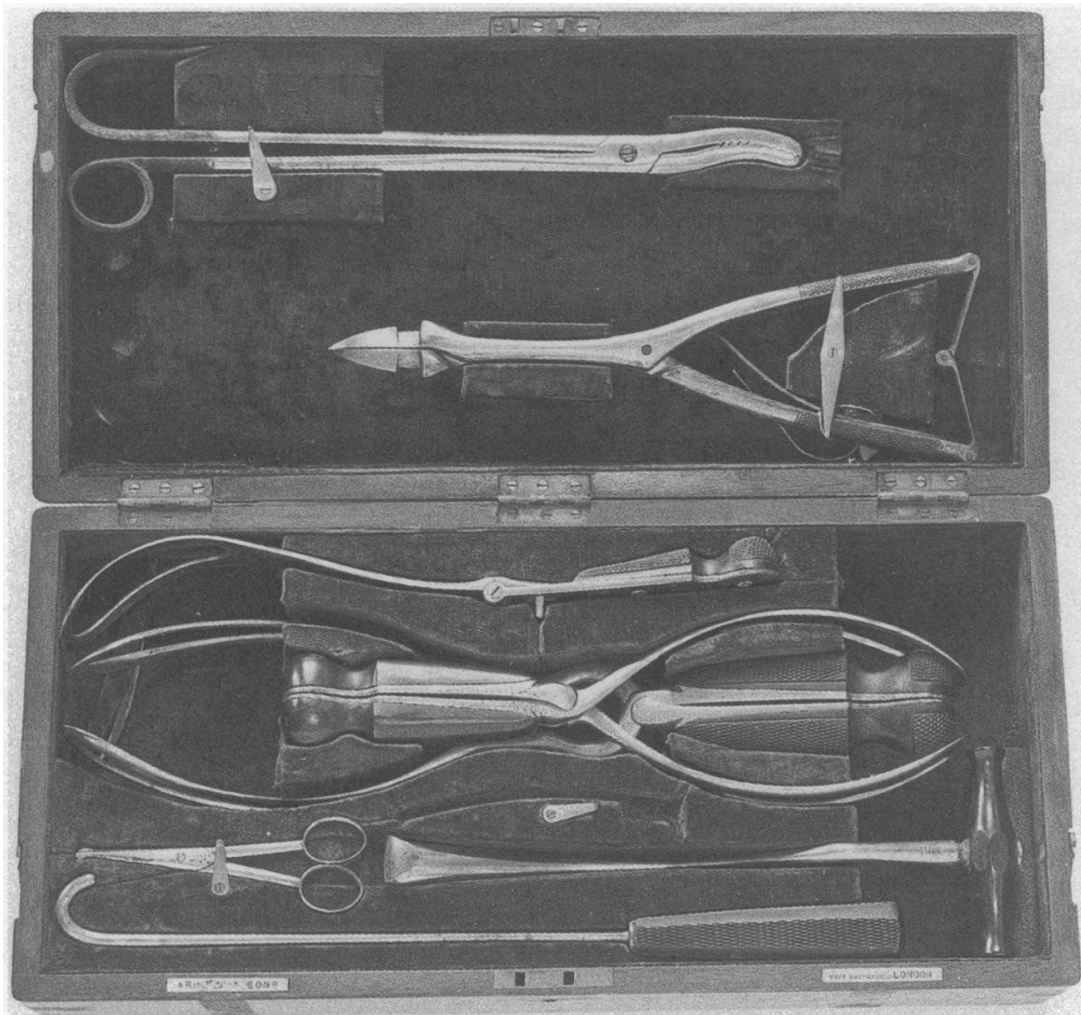

Figure 24: Mid-nineteenth-century obstetrical case. (Wellcome Library, London.) 
but I believe, did not injure the right carotid - I am astonished, he attempted such an operation - but I believe he will try[?] at anything no matter however hazardous ${ }^{58}$ - the poor patient seems exceedingly faint $\&$ ill - vomited during the operation $\& c$. I sh ${ }^{d}$. not be at all surprized, if he died a few hours after. Went down to Guersant's today - removed the arm - \&c. At $\mathbf{M}^{\mathrm{e}}$. Lachapelle's we commenced the Manoeuvres des Accouchemens contre Nature $^{59}$ - these I hope to learn a great deal from. At all events it ought to give me some confidence.

/69r/ Wednesday $27^{\text {th }}$.

Went to Hospital $S^{t}$. Louis this morning to hear M. Alibert - he is a most original genius he lectures on Mellitopa ${ }^{60} \&$ Dartre $^{61}$ Rougeaule[?] ${ }^{62}$ - he is a good practitioner - I have no doubt - his names are exceedingly puzzling - At $\mathbf{M}^{\mathrm{e}}$. Lachapelle's cont ${ }^{\mathrm{d}}$. the manoeuvres contre nature.

Thursday $28^{\text {th }}$.

Went to Hotel Dieu this morning - intended to go on to H. $\mathrm{S}^{\mathrm{t}}$. Louis, but it was so cold \& appeared so likely to rain, that I did not do so - this is the grand fête de l'Ascension. ${ }^{63}$ Went to the Ecole Pratique, ${ }^{64}$ but found every thing closed - no operations going on - the man on whom Roux operated on Tuesday appeared very poorly.

Friday $29^{\text {th }}$.

Miserable weather. Went to Hotel Dieu. Went round with Breschet \& attended his consultation - he had nothing particular there. Went to $\mathbf{M}^{\mathrm{e}}$. Lachapelle's again this Evening - it takes up immense time - I am there nearly 3 hours - still on turning. ${ }^{65}$

Saturday $30^{\text {th }}$.

Miserably cold. Went down to H. Dieu with Roux - his case dead - he had a few operations on cataract today - did not stay to see them - went into Breschet's wards - nothing particular except two or three cases of varicocele - at his consultation he removed an enlarged tonsil

\footnotetext{
${ }^{58}$ An example of what the diarist perceives as self-serving surgery, which is indifferent to the patient's suffering. See Introduction, p. 24, for a discussion of the diarist's attitude to some of the Parisian surgeons.

${ }_{59}$ Manoeuvres des Accouchemens contre Nature: literally, "manipulation of unnatural deliveries", which would include breech births, frequently hazardous to both infant and mother.

${ }^{60}$ The diarist could be referring to the condition of melituria (or mellituria) or méliturie, also known as glycosuria, which is not diabetes but in which, nevertheless, appreciable quantities of sugar were known to appear in the urine. It could occur in lying-in women. (Nysten, Dictionnaire de médecine, pp. 873, 645.)

${ }^{61}$ Dartre: generic name for various skin diseases. It also applies to the scab or crust sometimes formed in such conditions.

${ }^{62}$ Probably a reference to rougeole, the measles, a condition which definitely manifests itself through symptoms on the skin as well as a high fever.

${ }^{63}$ Fête de l'Ascension: Ascension day, on which the Virgin Mary ascended into heaven. One of the great days in the ecclesiastical calendar of the Roman Catholic Church, which carried an obligation to attend Mass.

${ }^{64}$ Ecole Pratique: this was one of the two (the other being Clamart) large dissecting establishments set up early in the nineteenth century as part of the reform of medical education and in fulfilment of the need to replace, on grounds of public health, the various small uncontrolled dissecting rooms scattered around Paris. It was controlled by the faculty of the École de Médecine nearby. (Warner, Against the spirit of system, pp. 95-6.)

${ }^{65}$ Turning: a component of the manoeuvres the diarist is learning with Mme Lachapelle. Thus when the foetus is in the breech position, attempts are made to turn the foetus in utero in order to manoeuvre the head into the normal position where it will leave the uterus first in its passage along the birth canal.
} 
with the Pinces de Musean ${ }^{66} \&$ a probe pointed bistouri. At Guersant's performed operation of trepan. ${ }^{67}$ At $\mathbf{M}^{\mathrm{e}}$. Lachapelle's still turning.

Sunday $31^{s t}$.

Weather somewhat improved today. Went twice to the R. d'Anjou - in the morning sermon on the Ascension, in the afternoon on Noah.

${ }^{66}$ Pinces de Musean: the instrument for the removal of enlarged tonsils, later renamed the amygdalotome, which is illustrated in Larousse médical, p. 899.

${ }^{67}$ Trepan: this is the instrument used by surgeons to remove a portion of bone from the skull. The diarist probably meant to write, "trepanning", the operation itself. 